International Journal of Economics, Business and Accounting Research (IJEBAR)

Peer Reviewed - International Journal

Vol-4, Issue-2, 2020 (IJEBAR)

E-ISSN: 2614-1280 P-ISSN 2622-4771

https://jurnal.stie-aas.ac.id/index.php/IJEBAR

\title{
HOW DOES THE EFFECT OF CORPORATE ETHICS AND POLITICAL BAHAVIOR AGAINST ORGANIZATIONAL COMMITMENTS?
}

\author{
R. Iqbal Robbie \\ Faculty of Economics and Business, University of Muhammadiyah Malang \\ Email:iqbal_robbie@umm.ac.id
}

\begin{abstract}
The ethical value is part of the organizational culture, as an organizational environment that plays a role in forming employee organizational commitment. This study aims to determine the effect of a ethical values on organizational commitment with political behavior as a mediating variable. This research is a positivist approach or a quantitative approach because it tests existing variables. The ethical value is based on the diversity of situations and conditions in the company and personal behavior within the leader in using political influence to enable conflict or good synergy between employees. The population of this study were all employees other than the Head of the Office both PNS and non PNS under the Investment and Integrated Services Office of the Pasuruan City Government, amounting to 90 people. Research variables will be elaborated through a questionnaire which will be distributed to respondents based on the total number, because it uses census research. The collected data will be processed using smart PLS analysist
\end{abstract}

Keywords: $\quad$ ethical values, organizational commitment, political behavior

\section{Introduction}

Urban areas in Indonesia have typical problems, including urbanization, the environment and social issues. Various urban problems arise due to unclear urban spatial planning, and inconsistency of policy makers in implementing development planning. In general, the executive and legislative branches still think conventionally, and do not have a clear and explicit development concept. There are two things to address the problem of urban development, namely planning and development. However, the problem actually starts with the policy of the regional government itself, which deviates from the city spatial plan. The local regulation that is derived from urban spatial planning is only a concept of formality. Because the regional government is not consistent in carrying out development planning, not to mention the lack of effectiveness and coordination between agencies and agencies.

The second problem is integration between cities and districts, namely the issue of regional disparity. To create a comfortable city, city planning must be carefully planned. The situation in East Java already has a Regional Spatial Plan (RTRW), but the implementation is not in accordance with what has been determined by the government. Because of that many violations committed and left. For example, for example in the city of Malang, mall construction is not in accordance with the regency / city RTRW plan, it turns out that when the community protested against the development, but it still proceeded without any clear sanctions. There is an example of the Lapindo mud problem which has no plans to replace a damaged room, such as an access road to Surabaya or other cities, thus disrupting the community's economy. Another problem is related to the construction of the South Ring Road (JLS) which has not been completed.

The government lacks the ability to anticipate problems in the future. Since there was regional autonomy, the center no longer had a portfolio on urban areas. So when asked about city development policies, no one dares say responsibility. With population urbanization, the agricultural sector which is the mainstay of rural areas is now contributing to $15 \%-20 \%$ of national GDP. Then, the village process that turns into a city, is 
International Journal of Economics, Business and Accounting Research (IJEBAR)

Peer Reviewed - International Journal

Vol-4, Issue-2, 2020 (IJEBAR)

E-ISSN: 2614-1280 P-ISSN 2622-4771

https://jurnal.stie-aas.ac.id/index.php/IJEBAR

not only a social problem, but also an environment, an extraordinary function change in rural areas, which results in disasters that we feel in urban areas.

According to Pfeffer (1995) organizations can successfully compete through the management of their potential HR. HR can be used as a source of competitive advantage and competitors are not easily imitated because managing HR is influenced by company culture. This organizational culture will affect the skills, abilities and suitability of the existing system. Pasuruan as a city in the golden triangle of East Java has a very strategic location, because it is a supporting city for Surabaya as the capital of East Java. However, the City Government has a very complicated problem too, because like a city that has lost its parent, this is marked by the Mayor of Pasuruan who is affected by criminal problems, resulting in somewhat disrupted operations.

In the business environment, the Pasuruan City bureaucracy is also known to be complicated. Moreover, there is the problem of the head of government in this case the Mayor of Pasuruan was hit by a criminal problem. This is a question of how existing employees' commitment in carrying out their duties and obligations. The problem that arises is the discipline of City Government employees who generally seem low which ultimately results in low work commitment. At present there are still many problems affecting the public regarding public services, such as the problem of applying for licenses, public services, and the slow process of development. Problems arise from the community as people are not satisfied with the services provided, and some internal factors on the performance of public servants in the office or service such as office hours which are delayed from the specified hours and the reason there are still many other more important jobs that are still piling up, will but by giving a stimulus we can get the service we want. Though the function of the organization is none other than to serve the interests of the wider community. This condition can be said as a violation of work discipline, because the employees do not act or behave in accordance with the rules and procedures set by the organization.

In this study, the main problem as outlined above is the commitment of employees with the object of research are the employees of the Pasuruan City Government especially the Investment and Integrated Services Office as a miniature of the collection of Services in the Pasuruan City Government. This DPPMPT is used as a purposive sample as a representation of the performance of existing employees because various existing Offices in the City Government are merged into one roof, such as representatives of Public Works (PU) and Cipta Karya also are placed in the DPPMT Service. Robbins (2006) mentions that there is a weak corporate work culture and a strong corporate work culture. The difference is that a strong corporate culture will also have a strong influence on employees such as the level of togetherness and intensity between members to jointly uphold the control of the implementation of the work culture. Dimensions of corporate culture are beliefs, norms and values. Beliefs or trust is the employee feels confident and believes that the culture in the company will have a good impact on organizational life, by seeing and obeying the norms, regulations that apply so that it will provide values or values that are very valuable to the employee and the company.

\section{Literature Review}

\section{Corporate Ethical Value}

The company's ethical value scale from Hunt, et al. (1989) is often used as a survey tool for any action related to employees' ethical perceptions in relation to managers or companies. It was developed to find out: (a) The extent to which employees see manager's behavior acting ethically in the organization, (b) The extent to which employees feel that managers are paying attention to ethical issues in the company and (c) The extent to which employees feel that ethical behavior or unethically appreciated in the organization 
International Journal of Economics, Business and Accounting Research (IJEBAR)

Peer Reviewed - International Journal

Vol-4, Issue-2, 2020 (IJEBAR)

E-ISSN: 2614-1280 P-ISSN 2622-4771

https://jurnal.stie-aas.ac.id/index.php/IJEBAR

Corporate ethical values can be explained as part of corporate culture that represents various multidimensional interactions in formal and informal behavioral control systems (Trevino et al., 1998). Informal systems consist of values, attitudes, norms, perceptions and beliefs in organizations (Key, 1999; McDonald and Nijhof, 1999). Ethical leadership and ethical values and corporate behavior demonstrate the positive role of ethical leadership in employees as role models (Whitmeyer, 2000). In connection with this informal aspect of the company's ethical values can also be expressed with a strong formal structure such as compensation methods, institutional procedures, and applicable regulations. Research conducted by Iqbal (2013) with the title corporate ethical values, group creativity, job commitment and performance: the effect of work response on work context conducted on the three largest telecommunications companies in Pakistan, states that the ethical values of companies have a significant influence on performance.

Some previous studies on the ethical value of companies, there are still mismatches such as Rehman (2012) who found a significant influence between the ethical values of companies on ethical leadership. But research conducted by Schimmuller (2012) explains that certain organizational cultures will affect leadership positively or have no effect at all. In the above research, the relationship between the ethical values of companies as part of organizational culture is related to leadership. There are other studies, the relationship between the ethical values of companies with organizational commitment conducted by Zain, et al. (2009) Organizational culture has a positive effect on employee commitment, this is contrary to research conducted by Erben and Guneser (2008) who found that organizational culture only had a significant effect on affective and continuance commitment, but did not affect normative commitment. Differences in organizational performance are strongly related to the strategies and rules adopted by companies to achieve their goals (Amah et al., 2013). Corporate culture as a set of values, norms and strategies plays an important role in the success of company performance (Daft, 2003).

\section{Organizational Commitment}

Mathis and Jackson (2000) provide the definition, "organizational commitment is the degree to which employees believe in and accept organizational goals and desires to remain with the organization". (Organizational commitment is the degree to which employees believe and accept the goals of the organization and will remain or will not leave the organization). Robbins (1989) defines organizational commitment as an attitude that reflects the likes or dislikes of employees towards the organization. Steers and Porter (1983) say a form of commitment that arises not only passive loyalists, but also involves an active relationship with work organizations that have the goal of making every effort for the success of the organization concerned. Commitment has been used by organizations to predict desired employee behavior in the areas of performance, absenteeism and emotional attachment.

Theoretically, organizational commitment has three components (Meyer and Allen, 1991): affective, continuous and normative.

1. Affective commitment is explained as an employee having an emotional attachment to the organization. 2. Continuous commitment is the economic value that is felt by the organization compared to leaving it, arising when employees remain in an organization because they need a salary or other benefits.

3. Normative commitment is an obligation to remain with the organization for moral or ethical reasons, arising from values in employees. Employees remain members of the organization because of the awareness that commitment to the organization is the right thing to do.

\section{Political Behavior}

Several studies have found various definitions and terms for political behavior, namely politics in an organization. Based on the literature review, we can conclude that the different terms all involve the same definition of "action" which has a meaning similar to "behavior". 
International Journal of Economics, Business and Accounting Research (IJEBAR)

Peer Reviewed - International Journal

Vol-4, Issue-2, 2020 (IJEBAR)

E-ISSN: 2614-1280 P-ISSN 2622-4771

https://jurnal.stie-aas.ac.id/index.php/IJEBAR

Political behavior means any form of official operational action that is considered as an illegal or illegal use of power according to company rules. Behavioral politics is the means by which people gain power over individuals, groups, and companies to gain personal interest in themselves, or whatever the group means, and also to maintain personal (and / or their group) power. According to Moorhead and Griffin (2010), there are eight indicators in political behavior variables: 1) controlling information; 2) controlling the communication lines; 3) using outside experts; 4) controlling the agenda; 5) playing a game; 6) build image; 7) build coalitions; and 8) controlling decision parameters

The study of the correlation between political behavior and job satisfaction by Kulachai (2009) shows that organizational political perceptions have a positive influence on political behavior. Perceptions of political organization can reduce job satisfaction, organizational commitment, citizenship behavior, and task performance, and cause an increase in psychological tension (Chang et al., 2009 as quoted in Guclu, Mahmoud, Bryan, \& Barry, 2010). Perceptions about self-promotion and seditious behavior are negatively related to job satisfaction, especially from supervisors, and positively related to intention to move (Cook, Ferris, \& Dulebohn, 1999)

\section{Hypothesis Model}

Based on the explanation above, the hypothesized model in this study is as follows:

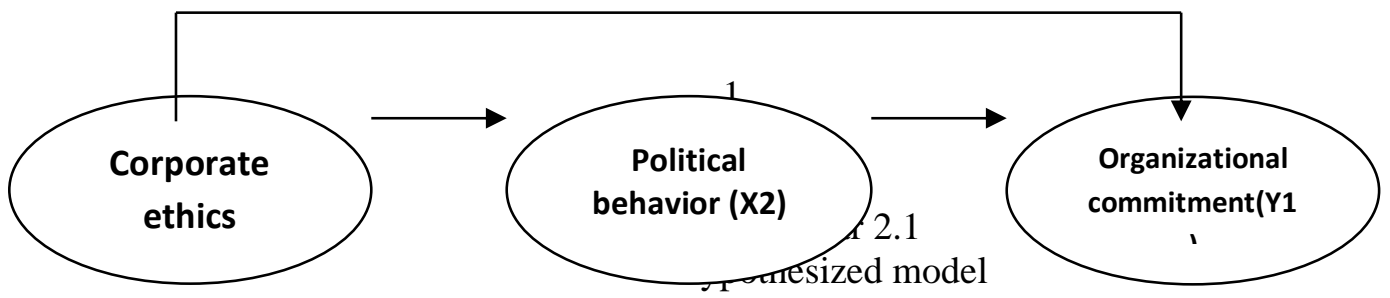

Based on these images, a summary of the hypothesis as explained above this study is:

1. Organizational ethical values influence political behavior

2. The ethical value of the organization influences organizational commitment

3. Political behavior influences organizational commitment

4. Political behavior as a mediating variable, the influence of ethical values on organizational commitment

\section{Research Methodology}

This study uses a positivist or quantitative approach because it aims to test hypotheses. The hypothesis is based on the research questions that have been prepared. Research questions are arranged based on theoretical studies, previous research studies and from existing phenomena. Hypothesis testing is needed to obtain an explanation of the causal relationship between research variables (causality). Explanation of the results of the study also refers to various references to the main theories used, the results of previous studies and interviews of selected respondents.

\section{Research Population}

The population of this study (unit of analysis) is all employees totaling 90 people under the sub-sector in the Office of Investment and Integrated Services of Pasuruan City Government who have duties and responsibilities related to the implementation of organizational operations. This study uses a census population or all employees as research objects. This type of organization is the SKPD (regional work unit) contained in the Pasuruan City Government.

Reasons for Population Selection 
International Journal of Economics, Business and Accounting Research (IJEBAR)

Peer Reviewed - International Journal

Vol-4, Issue-2, 2020 (IJEBAR)

E-ISSN: 2614-1280 P-ISSN 2622-4771

https://jurnal.stie-aas.ac.id/index.php/IJEBAR

The selection of population areas is based on the desire of researchers to fully understand the views of these employees in carrying out their work responsibilities. This research is expected to explore the reasons for the practice of social responsibility in certain areas related to the values of social norms and political behavior. Determination of the location, because the Pasuruan City Government is a government organization that is in the spotlight as a public organization that lost its head of government. Pasuruan City Government is a golden triangle because it is located near Surabaya as the center of East Java's economy so it needs to be continuously improved, especially in terms of employee commitment as a form of responsibility to the community. While the DPMPT Office was chosen because the service was representative of all departments in the Pasuruan City Government.

The inferential statistical analysis approach in this study is Partial Least Square (PLS) which is calculated using SmartPLS 3.0 software. PLS itself is a PLS Structural Equation Model (SEM) equation model that experienced a shift from covariant-based to variant-based (Ghozali, 2015). PLS can be used to confirm a theory and can be used to build relationships that do not yet have a theoretical foundation. The purpose of this study was to examine the predictive effect between latent variables (PLS analysis is done by evaluating two models namely the outer model (measurement model) and inner model (structural model). The measurement model is used to test the validity and reliability. While the structural model is used to show the specification of the relationship between latent variables, namely between exogenous variables and endogenous variables (Ghozali, 2015). The measurement model is done by comparing the value of R2 construct and measuring the value of Q2. Next, hypothesis testing is performed using t-statistic values

\section{Results and Discussion}

Characteristics of respondents in this study describe the sex, age, years of service, education level, and position of the respondent. it is known that of the 90 employees in the Pasuruan City Government DPMPT who participated in this study at most $57.7 \%$ of employees were male, and $42.3 \%$ of employees were female. From the results of the analysis more employees are male because DPMPT requires more staff who are agile outside the office to carry out surveys and field checks. A total of 90 employees in DPMPT Pasuruan City participated in this study with a maximum of 31.1\% of employees aged 31-40 years and 4150 years. From the analysis results it is known that employees with the largest proportion are in the above age range, this shows that the age can be said to be productive for working actively, and that the age of maturity is more functioned as a guide for young employees.

Based on the results in the table above, it is known that of the 90 DPMPT Pasuruan City employees who participated in this study at most 55.6\% of employees had worked for 1-3 years. This shows that employees in the service are rolling employees from various departments in the Pasuruan City Government to run dynamically.

Based on the results in the table above, it is known that of the 90 DPMPT Pasuruan City employees participating in this study, at most $81.1 \%$ of employees had an educational background in S1. Then $18.9 \%$ of employees have S2 education background. From the data above, it shows that employees already have the most position level is staff at $81.1 \%$, others are evenly distributed such as the Head of the Division and the Head of the Subdivision.

\section{Partial Least Square Analysis (PLS) \\ Measurement Model Analysis Validity Testing}

An item is said to be valid if the loading factor is positive and is greater than 0.6 (Hair, et al. 2014). Based on the results of the analysis of the 1st order measurement model it can be seen that all indicators that measure the dimensions of the formal system, the informal system, political behavior and organizational 
International Journal of Economics, Business and Accounting Research (IJEBAR)

Peer Reviewed - International Journal

Vol-4, Issue-2, 2020 (IJEBAR)

E-ISSN: 2614-1280 P-ISSN 2622-4771

https://jurnal.stie-aas.ac.id/index.php/IJEBAR

commitment variables produce a loading factor greater than 0.6. Thus the indicators that measure these dimensions or variables are declared valid. Convergent Validity 1st test results can be seen through the table below:

Table 1. Convergent validity testing

\begin{tabular}{|l|l|c|}
\hline Variable & Indicator & Loading Factor \\
\hline \multirow{3}{*}{ Ethical values } & Formal system & $\mathbf{0 . 9 5 9}$ \\
\cline { 2 - 2 } & Informal system & $\mathbf{0 . 7 7 3}$ \\
Political behavior & $P P$ & 1.000 \\
\hline \multirow{3}{*}{ Organizational } & Normative & 0.892 \\
commitment & Afective & $\mathbf{0 . 6 9 3}$ \\
& Continuance & 0.870 \\
\hline
\end{tabular}

The formal system indicator has a loading factor of 0.959 , indicating that the indicator is a dominant indicator in measuring the representation of the agency's ethical value variables. While the political behavior indicator has a loading factor of 1,000 showing that indicator as a dominant indicator in measuring the political behavior variable. The normative commitment indicator has a loading factor of 0.892 , indicating that the indicator is a dominant indicator in measuring organizational commitment variables.

\section{Reliability Testing}

Calculations that can be used to test construct reliability are Cronbach alpha and composite reliability. Test criteria state that if composite reliability is greater than 0.7 (Hair, et al., 2014). and Cronbach alpha value greater than 0.6, the construct is declared reliable (Hair, et al., 2014). Calculation of composite reliability and Cronbach Alpha:

Table 2. reliability testing

\begin{tabular}{|c|l|l|l|}
\hline Variable & Indicator & $\begin{array}{l}\text { Composite } \\
\text { Reliability }\end{array}$ & $\begin{array}{l}\text { Cronbachs } \\
\text { Alpha }\end{array}$ \\
\cline { 1 - 1 } Ethical values & $\begin{array}{l}\text { NE1 } \\
\text { NE2 }\end{array}$ & 0.862 & 0.720 \\
\cline { 1 - 1 } $\begin{array}{c}\text { Political } \\
\text { behavior }\end{array}$ & PP & 1.000 & 1.000 \\
\cline { 1 - 1 } $\begin{array}{c}\text { Organizational } \\
\text { commitment }\end{array}$ & KO1 & 0.862 & 0.777 \\
\hline
\end{tabular}

Based on the table above it can be seen that the value of composite reliability on the dimensions of NE1, $\mathrm{NE} 2, \mathrm{PP}, \mathrm{KO} 1, \mathrm{KO} 2$, and $\mathrm{KO} 3$ is greater than 0.7 . Thus, based on the calculation of composite reliability, all indicators are declared reliable. Furthermore Cronbach's Alpha values on the dimensions NE1, NE2, 
International Journal of Economics, Business and Accounting Research (IJEBAR)

Peer Reviewed - International Journal

Vol-4, Issue-2, 2020 (IJEBAR)

E-ISSN: 2614-1280 P-ISSN 2622-4771

https://jurnal.stie-aas.ac.id/index.php/IJEBAR

$\mathrm{PP}, \mathrm{KO} 1, \mathrm{KO} 2$, and $\mathrm{Ko} 3$ are greater than 0.6. Thus, based on Cronbach's Alpha calculations all indicators are reliable.

\section{Results of Analysis of Research Models Goodness of Fit Model}

Goodness of fit model is used to determine the ability of endogenous variables to explain the diversity of exogenous variables, or in other words to determine the contribution of exogenous variables to endogenous variables. Goodness of fit Model in PLS analysis is performed using Q-Square predictive relevance $(\mathrm{Q} 2)$.

Table 3. Goodness fit of models

\begin{tabular}{|c|c|}
\hline Variable & $\boldsymbol{R}_{\mathbf{2}}$ \\
\hline Political behavior & 0.049 \\
\hline Organizational commitment & 0.182 \\
\hline $\mathrm{Q}_{2}=1-\left(1-\mathrm{R}_{12}\right)\left(1-\mathrm{R}_{22}\right) \rightarrow$ \\
$\mathrm{Q}_{2}=1-(1-0.049)(1-0.182)=0.223$ \\
\hline
\end{tabular}

The R-square variable of political behavior is 0.049 or $4.9 \%$. This can indicate that the diversity of political behavior variables is explained by the company's ethical value variable by $4.9 \%$, or in other words the contribution of the company's ethical value variable to the political behavior variable by $4.9 \%$, while the remaining $95.1 \%$ is the contribution of other variables not discussed in the study this.

Furthermore, the R-square variable organizational commitment is 0.182 or $18.2 \%$. This can indicate that the diversity of organizational commitment variables is explained by the variable ethical values and political behavior by $18.2 \%$, or in other words the contribution of the variable ethical values and political behavior to organizational commitment variables by $18.2 \%$, while the remaining $82.8 \%$ is contributed by other variables not discussed in this study.

\section{Research Hypothesis Testing Results}

The results of the PLS analysis produce a path diagram of the relationship between the research variables both directly and indirectly as follows:

Hypothesis testing is used to test whether there is an influence of exogenous variables on endogenous variables. The test criteria state that if the value of t-statistics $\geq t$-table (1.96) then it is stated that there is a significant influence of exogenous variables on endogenous variables (Hair, et al., 2014).

Table 4. Research Hypothesis Testing Results

\begin{tabular}{|c|c|c|c|c|}
\hline Variables effect & $\begin{array}{l}\text { Original } \\
\text { Sample } \\
(\mathbf{O})\end{array}$ & $\begin{array}{l}\text { Standard } \\
\text { Error } \\
\text { (STERR) }\end{array}$ & \begin{tabular}{|l} 
t-statistics \\
(O/STERR)
\end{tabular} & Keterangan \\
\hline Ethical values - > Political & 0.221 & 0.102 & 2.164 & Sign \\
\hline Ethical values - > Commitment & 0.284 & 0.129 & 2.197 & Sign \\
\hline Political - > Commitment & 0.262 & 0.104 & 2.512 & Sign \\
\hline Ethical values*political -) Commitment & 0.058 & 0.057 & 1.551 & No Sign \\
\hline
\end{tabular}


International Journal of Economics, Business and Accounting Research (IJEBAR)

Peer Reviewed - International Journal

Vol-4, Issue-2, 2020 (IJEBAR)

E-ISSN: 2614-1280 P-ISSN 2622-4771

https://jurnal.stie-aas.ac.id/index.php/IJEBAR

The results of the analysis of the path of direct influence or indirect influence between research variables, it can be used to test the research hypothesis. The results of the research hypothesis test are explained in the following sections.

Hypothesis 1: Ethical Value will have an influence on Political Behavior

Hypothesis test results of the influence of ethical values on political behavior produce a path coefficient of 0.221 with a t-statistics value of 2.164. The test results show that the value of t-statistics> 1.96 . This means that there is a significant influence of ethical values on political behavior. These results accept Hypothesis 1 of the study that the stronger the ethical values will improve political behavior in the DPMPT service.

Hypothesis 2: The stronger the Ethical Value, will affect the Organizational Commitment of Employees

Hypothesis test results the influence of ethical values on organizational commitment produces a path coefficient of 0.284 with a t-statistics value of 2.197 The test results indicate that the value of t-statistics $<1.96$. This means that there is a significant influence of ethical values on organizational commitment. These results accept Hypothesis 2 research that the stronger the ethical values, will affect the organizational commitment of employees.

Hypothesis 3: Political behavior has an influence on employee organizational commitment

Hypothesis test results of the influence of political behavior on organizational commitment produce a path coefficient of 0.262 with a t-statistics value of 2.512 . The test results show that the value of t-statistics> 1.96. This means that there is a significant influence of political behavior on organizational commitment. These results accept Hypothesis 3 research that the stronger political behavior will have an influence on employee organizational commitment.

Hypothesis 4: Political behavior as a mediating influence between ethical values on organizational commitment

The results of the hypothesis testing of political behavior as a mediating influence between ethical values on organizational commitment indirect effect produces a path coefficient of 0.058 with a statistical value of 1.551. the test results show that political behavior cannot mediate the relationship between ethical values and employee organizational commitment.

\section{Discussion}

\section{The influence of ethical values on political behavior}

Culture as a system of social control is a pattern of behavior or organizational style that tends to persist over time so as to explain what they have to do or say in certain situations. In this sense ethical values will provide stability of behavior, both related to what individuals do at different times, but also what individuals can do at the same time.

Ethical values provide perceptions and values that are established, the stronger people can associate themselves with the mission of their organization and feel an important part of it, and ethical values result in a commitment to completing the mission of the organization. In the results of this study, ethical values as part of the organizational culture owned by the DPMPT Pasuruan City Government have a significant influence on political behavior. Ethical values can be the basis for how the political behavior of leaders in providing effective communication and organizing information for employees in carrying out their duties and obligations.

The results of this study indicate support for the hypothesis that the stronger the ethical values possessed by the agency will increase the political behavior held by the agency's head of service. Attitudes and behaviors of leaders and employees in applying ethical values must receive more attention, because understanding and actions regarding the ethical values contained will lead to an identity for the behavior of all members. 
International Journal of Economics, Business and Accounting Research (IJEBAR)

Peer Reviewed - International Journal

Vol-4, Issue-2, 2020 (IJEBAR)

E-ISSN: 2614-1280 P-ISSN 2622-4771

https://jurnal.stie-aas.ac.id/index.php/IJEBAR

\section{The Effect of Ethical Value on Organizational Commitment}

Interaction in agency culture between leaders and employees who perform daily work interactions is likely to have an impact that can be directly seen and felt by subordinates. The results of this study indicate that there is an influence between ethical values on employee organizational commitment. Ethical value is a system of meaning that must be infused by all employees, there are goals that are conceptual and there are technical ones. For the top level management it is easier to understand the value that is in the company, but for the lower level management it is more difficult to understand the value contained in the company. As a result, ethical values have a significant effect on increasing employee organizational commitment. This ethical value must be forced, although there will be inner turmoil, but from this coercion will arise habits and later become a culture for employees.

\section{Effect of Political Behavior on organizational commitment}

Political behavior absolutely needs to be done by the leadership of the agency to smooth the implementation of activities, for example using a structured schedule to be able to accomplish the tasks that must be done. By integrating various leadership styles, the findings of this study provide a firmer impact that political behavior has the highest urgency in the effective leadership factor. Especially in the relationship between company members, leader ethics is a distinguishing factor that will always be imitated and followed by company members.

\section{Political behavior as a mediating relationship between ethical values and employee organizational commitment.}

Political behavior is the means by which people gain power over individuals, groups, and companies to gain personal interest in themselves, or whatever the group means, and also to maintain personal (and / or their group) power. This is what is still seen by employees that in understanding ethical values do not require political means, because ethical values are more directed towards morality that will bind employee behavior. So politics cannot be a medium for how ethical values will significantly influence the commitments held by the agency's employees.

\section{Conclusions And Recommendations}

\section{Conclusions}

a. Ethical values as a guideline for agencies must be managed well, change of leaders will not have a big influence if the cultural system is strengthened.

b. The attitude of the leadership in reflecting political behavior is part of management in developing the company's sustainability value. Guaranteeing ethical values is a responsibility that has power, legitimacy and strong urgency.

c. The stronger the meaning of organizational commitment, the better the behavior of members, styles and patterns of institutions increasingly shows morality both at work and as individuals outside the workplace

d. The behavior of the leadership should reflect how ethical values are inherent in the leadership pattern of the agency, so politics does not need to stand out in overcoming all agency issues

\section{Suggestions}

\section{Advice for Management}

a. Leaders need to explore ethical and legal factors so as to make it easier to understand the demands of how to shape and strengthen ethical values with their stakeholders. 
International Journal of Economics, Business and Accounting Research (IJEBAR)

Peer Reviewed - International Journal

Vol-4, Issue-2, 2020 (IJEBAR)

E-ISSN: 2614-1280 P-ISSN 2622-4771

https://jurnal.stie-aas.ac.id/index.php/IJEBAR

b. Understanding the ethical and legal aspects, the leader can design strategies, operational planning, build governance and work systems that are more in line with the economic and social realities of the company and provide direct economic benefits to the company.

\section{References}

Connell. 1995. Relationships Between Organizational Culture and Organizational Performance, Psychological Reports 76(2), 483-492.

Goldman, A., \& Tabak, N. (2010). Perception of ethical climate and its relationship to nurses' demographic characteristics and job satisfaction. Nursing Ethics, 17(2), $233 \mathrm{e} 246$.

Guclu, A., Mahmoud, D., Bryan, F., \& Barry, W. P. (2010). Perceptions of organizational politics: A meta-analysis of theoretical antecedents. Journal of Managerial Issues, 22(4), 494e515.

Kalshoven, K., Den Hartog, D. N., \& De Hoogh, A. H. B. (2011). Ethical leadership at work questionnaire (ELW): Development and validation of a multidimensional measure. The Leadership Quarterly, 22, 51e69.

Kim, W. G., \& Brymer, R. A. (2011). The effects of ethical leadership on manager job satisfaction, commitment, behavioral outcomes, and firm performance. International Journal of Hospitality Management, 30, $1020 \mathrm{e} 1026$.

Kulachai, W. (2009). Organizational politics and police officers' attitude towards organizational efficiency: A case study of Metropolitan Police Bureau (Research Report). Bangkok, Thailand: Ramkhamhaeng University. [in Thai]

Luthans, F. (2007). Organizational behavior (11th ed.). Singapore: McGraw-Hill Inc.

Moorhead, G., \& Griffin, R. W. (2010). Organizational behavior: Managing people and organizations (9th ed.). Hong Kong, China: China Translation \& Printing Services Limited.

Okpara, J. O., \& Wynn, P. (2008). The impact of ethical climate on job satisfaction, and commitment in Nigeria: Implications for management development. Journal of Management Development, 27(9), 935e950.

Pio, R. J. (2000). The management of political behavior in organizations (Research Report).

Pratchayapruet, T. (2008). Professionalism and ethics. Journal of Thai Ombudsman, 1 (4), 25e80. [in Thai]

Riggio, R. E. (2009). Introduction to industrial/organizational psychology (5th ed.). Upper Saddle River, NJ: Pearson Education, Inc.

Saritwanit, S. (2009). Modern organizational behavior: Concept and theories (2nd ed.). Pathum Thani, Thailand: Thammasat University Publication. [in Thai]

Sasomsap, M. (2004). Relationships between self-esteem, ethical work climate, and job satisfaction as perceived by professional nurses, nonprofit private hospitals, Bangkok Metropolis (Rese

Sekaran, U., and Bougie, R. 2010. Research methods for business. A skill building Approach. 5th Ed. UK: John Willey.

Trevino, L., Butterfield, K.D. \& McCabe, D.L. (1998). The Ethical Context in Organizations: Influence on Employee Attitudes and Behaviors, Business Ethics Quarterly, 8, pp.447-476. 
International Journal of Economics, Business and Accounting Research (IJEBAR)

Peer Reviewed - International Journal

Vol-4, Issue-2, 2020 (IJEBAR)

E-ISSN: 2614-1280 P-ISSN 2622-4771

https://jurnal.stie-aas.ac.id/index.php/IJEBAR

U. Dhar, P. Mishra, Leadership effectiveness: A study of constituent factors. Journal of Management Research, 1(4) (2001) 254-263.

Valackiene, A. (2009). Theoretical Model of Employee Social Identification in Organization Managing Crisis Situations, Engineering Economics, 4, pp.95-101.

Valentine, S, Godkin, L., \& Lucreo, M. (2002). Ethical Context, Organizational Commitment and PersonOrganization Fit: Organizational Goal Congruence, Personnel Psychology, 44, pp.333-352 